\title{
Regeneration of bulblets on bulb scale segments of hyacinth in vitro ${ }^{1}$
}

\author{
R. L. M. Pierik \& M. A. Ruibing \\ Department of Horticulture, Agricultural University, Wageningen, the Netherlands
}

Received: 26 March 1973

\section{Summary}

In vitro culture was applied to study the regeneration and growth of bulblets on bulb scale segments of the hyacinth cv. 'Pink Pearl'. Particular attention was paid to plant factors, while also the effect of temperature, light and darkness was investigated.

The influence of the duration of dry storage at $25^{\circ} \mathrm{C}$ after harvest, studied from July till November, on the number of regenerated bulblets is small; bulblet growth, however, is optimal during the first weeks of October. When individual bulbs of the same harvest and size are compared, great differences in both regeneration ability and bulblet growth occur. A comparison of bulb scales demonstrates that the number of regenerated bulblets is not influenced by the scale number, but that bulblet growth is much better on bulb scales 7 to 18 as compared with bulb scales 1 to 6 . Both regeneration and growth of bulblets are strongly promoted when the explants are taken out of the proximal parts of a scale instead of the distal parts. When the length of proximal explants is increased, both regeneration and growth are promoted. Optimal regeneration and bulblet growth are obtained when the explants are placed inverted on the culture media. Although the speed of regeneration increases by raising the temperature from 8.8 to $24.8^{\circ} \mathrm{C}$, the number of bulblets per explant is optimal at $13{ }^{\circ} \mathrm{C}$, whereas optimal bulblet growth is obtained at $21.6{ }^{\circ} \mathrm{C}$ or at $24.8^{\circ} \mathrm{C}$. No differences in regeneration and growth of bulblets are observed when culture in continuous light is compared with that in darkness.

\section{Introduction}

For many years hyacinths have been propagated vegetatively by means of scooping, which involves the removal of the whole basal plate of a bulb by a curved-bladed scalpel or spoon so that only scales remain, which all regenerate bulblets at their basal ends.

In 1968 tissue culture techniques were applied to study the formation and growth of adventitious bulblets on isolated scale segments of hyacinth under controlled environmental conditions. The purpose of applying in vitro cultivation was also to find a new method to accelerate and to increase the multiplication rate of hyacinth, especially for the bulb breeder. An additional advantage of in vitro culture can be that if the

1 Publication 385, Laboratorium voor Tuinbouwplantenteelt, Landbouwhogeschool, Wageningen, the Netherlands. 
number of bud meristems can be promoted, a greater number of bulblets becomes available to obtain a pathogen-free stock via meristem culture.

This paper gives a survey of the influence of various plant factors which can affect regeneration and growth of bulblets, while also the influence of temperature, light and darkness is described. Some preliminary results were published previously (Pierik \& Woets, 1971).

\section{Material and methods}

All experiments were done with the hyacinth cv. 'Pink Pearl'. Bulbs were harvested on 17 June 1971 , dried for a few days at $25-30^{\circ} \mathrm{C}$ and then stored at $25^{\circ} \mathrm{C}$ until use. Only bulbs with a circumference of $17-18 \mathrm{~cm}$ were selected; care was taken that only undamaged bulbs were used to reduce the number of infections. The in vitro experiments were done from 15 July till the end of October 1971. Because Benomyl (or Benlate) sometimes had an unexpected effect on gladiolus corms (Forsberg, 1969), no Benomyl treatment was applied to our plant material.

The preparation of scale explants was done as follows. The outer dry and partly fleshy scales were removed; subsequently the basal plate was cut out, so that only fleshy scales remained, numbered from 1 (centre) to 18 (outer side). These scales were then carefully removed from the mother bulbs. In most experiments, except one, only scale numbers 7 to 18 were used and sterilized as follows: immersion in $70 \%$ ethanol for a few seconds, rinsing in $1 \% \mathrm{NaOCl}$ for 20 minutes and finally rinsing 4 times in sterilized tap water for 30 minutes. In nearly all experiments at least 3 bulbs were selected, from which explants from scales 7 to 18 were divided at random over the various treatments. Rectangular explants, in almost all experiments approximately $2 \mathrm{~cm}$ long and $1 \mathrm{~cm}$ wide, were cut out of the proximal (basal) parts of the scales. Scales 7 to 12 are smaller and yielded only 3 explants per scale; scales 13 to 18 , however, yielded 4 explants per scale. In one experiment a comparison was made between basal (proximal) and upper (distal) parts of the scales. In most experiments scale explants (24 per treatment) were placed inverted in the media to a depth of about half their lengths. Care was taken that the total inoculated fresh weight of the explants per treatment was approximately the same in all treatments, since the scales are not all of the same size and thickness. Each segment was wounded at all sides.

The original basic culture medium (Pierik \& Woets, 1971) was slightly modified and contained: Knop's macro-elements half strength, Heller's micro-elements full strength (except $\mathrm{FeCl}_{3}$ ), NaFeEDTA $25 \mathrm{mg} / \mathrm{l}$, glucose $2 \%$, Difco Bacto-agar $0.6 \%$ and pyrex distilled water. The media were autoclaved at $112^{\circ} \mathrm{C}\left(0.6 \mathrm{~kg} / \mathrm{cm}^{2}\right)$ for 20 minutes. Pyrex glass tubes (height $17 \mathrm{~cm}$, diameter $2.2 \mathrm{~cm}$ ) were plugged with cotton and after inoculation covered by aluminium foil.

In most experiments (except two) the test-tubes were incubated in a culture room at $25^{\circ} \mathrm{C}$ in continuous fluorescent light (Philips TL $40 \mathrm{~W} / 55$ ). The effect of temperature was examined in our phytotron (Doorenbos, 1964), where the light intensity is higher than in the culture room mentioned above.

The number of bulb-regenerating explants was scored after 4,8 and 12 weeks. At the end of the experiments, 12 weeks after isolation, the number of regenerated bulblets was counted and the fresh and dry weight (growth) of the regenerated bulblets determined. The mean number of bulblets per explant and the mean fresh and dry weight per explant were calculated over all isolated explants. Although root initiation was observed, root 
elongation was very poor in the inverted explants; for that reason no data on root formation are given in the tables.

The choice of the standard growth conditions and the plant material used in this study was based on the results described previously (Pierik \& Woets, 1971). The principle of all experiments in this paper was that in each experiment only one plant or environmental factor was varied, while all other factors were kept constant.

\section{Results}

\section{General observations}

In continuous light, the original white colour of the scales gradually disappeared and anthocyanin was formed so that after a few weeks the explants became violet-coloured. Within 2 weeks the cut surfaces healed and coloured brown, while a thin layer of callus appeared especially at the wounded basal sides of the explants. During the third week scale bases showed protuberances, which marked the beginning of macroscopically visible bulblet formation. After 4 weeks small bulblets could be observed. The developing leaves of these bulblets rapidly coloured green, although initially the outer scale of the new bulblets remained white to light-green with anthocyanin-coloured dots. In most cases bulblets were formed at the basal wounded ends of the explants. The number of bulblets formed at the outer (dorsal) sides of the explants was approximately

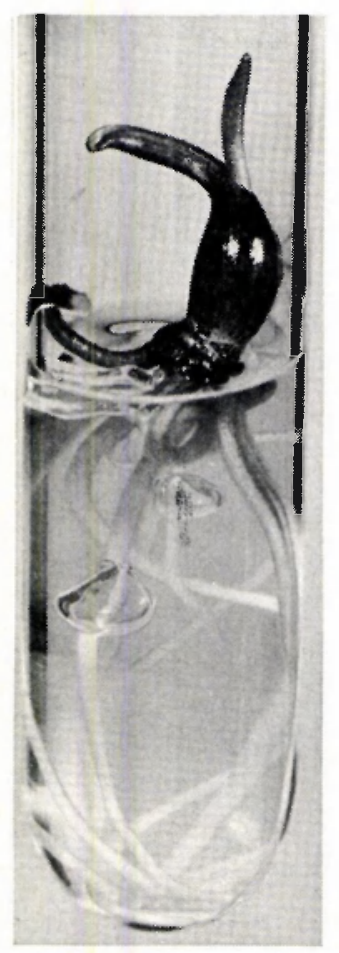

Fig. 1. Subculture on the basic medium of a hyacinth bulblet which was derived from a regenerated bulb scale explant. Photograph was taken 8 weeks after isolation of the bulblet. 
two times higher than at the inner (ventral) sides. Occasionally bulblets were formed at the dorsal or ventral flancs of the scale explants. The habit of the newly formed bulblets varied strongly: hardly any scale formation but only leaves, formation of 'unclosed' scales with leaves in the centre, formation of a typically 'closed' scale with leaves arising on the top of the scale, or sometimes only a 'closed' scale without leaves visible to the naked eye. When more than one bulblet was formed on an explant, in most cases the growth of one bulblet dominated, while the other bulblets remained smaller; this is possibly due to competition for nutrients and/or hormones.

During the 12 weeks of incubation two types of root primordia were formed on the basal sides of the explants: root primordia not connected with the regenerating bulblets and later, root primordia on the basal plates of the newly formed bulbs. Both types of root primordia, however, elongated poorly above the medium and in continuous light. When the regenerated bulblets were transplanted to fresh media, however, root primordia at the basal plates rapidly elongated into the medium and formed an extensive root system, even in continuous light (see Fig. 1).

\section{Duration of dry storage}

After harvest in June bulbs were dry-stored at $25^{\circ} \mathrm{C}$. Bulbs for the experiments were selected periodically from 15 July till the end of October. The question arose whether the duration of dry storage would influence the regenerative capacity. Table 1 (with average values of standard experiments in the various periods) shows that the number of bulblets was not influenced by the duration of dry storage; bulb weight per explant, however, increased gradually when the duration of dry storage increased, with an optimum in the period of 1 to 15 October.

Table 1. Effect of the period in which the experiments are performed (the duration of dry storage) on bulb regeneration and bulb weight.

\begin{tabular}{|c|c|c|c|c|c|c|}
\hline \multirow[t]{3}{*}{$\begin{array}{l}\text { Experiments } \\
\text { performed }\end{array}$} & \multicolumn{3}{|c|}{$\begin{array}{l}\text { Bulb regeneration } \\
\text { after } \ldots \text { weeks }(\%)\end{array}$} & \multirow[t]{3}{*}{$\begin{array}{l}\text { Number of } \\
\text { bulbs per explant } \\
\text { after } 12 \text { weeks }\end{array}$} & \multirow{2}{*}{\multicolumn{2}{|c|}{$\begin{array}{l}\text { Total bulb weight } \\
\text { per explant (mg) after } \\
12 \text { weeks }\end{array}$}} \\
\hline & \multirow[t]{2}{*}{4} & \multirow[t]{2}{*}{8} & \multirow[t]{2}{*}{12} & & & \\
\hline & & & & & fresh & dry \\
\hline 15-31 July & 36 & 84 & 93 & 1.6 & 35 & 7 \\
\hline 1-15 August & 29 & 72 & 87 & 1.8 & 34 & 10 \\
\hline 16-31 August & - & - & - & - & - & - \\
\hline 1-15 September & 23 & 75 & 83 & 1.7 & 38 & 11 \\
\hline 16-30 September & 30 & 76 & 81 & 1.6 & 42 & 12 \\
\hline 1-15 October & 28 & 81 & 92 & 1.8 & 55 & 15 \\
\hline 16-31 October & 21 & 78 & 81 & 1.5 & 40 & 11 \\
\hline
\end{tabular}

\section{Comparison of individual bulbs}

For all experiments scale segments were taken from at least 3 bulbs of the same harvest and size. Explants from these bulbs were always distributed at random over the various treatments of each experiment. The reason for this procedure was to smooth out as much as possible differences in regeneration capacity between the individual bulbs.

In Table 2 the results of one experiment, started on $29 \mathrm{July}$, are given in which the 
Table 2. Comparison of the regeneration ability and bulb weight of 7 individual hyacinth bulbs.

\begin{tabular}{|c|c|c|c|c|c|c|}
\hline \multirow[t]{3}{*}{ Bulb } & \multicolumn{3}{|c|}{$\begin{array}{l}\text { Bulb regeneration } \\
\text { after ... weeks }(\%)\end{array}$} & \multirow{3}{*}{$\begin{array}{l}\text { Number of bulbs } \\
\text { per explant } \\
\text { after } 12 \text { weeks }\end{array}$} & \multirow{2}{*}{\multicolumn{2}{|c|}{$\begin{array}{l}\text { Total bulb weight } \\
\text { per explant }(\mathrm{mg}) \text { after } \\
12 \text { weeks }\end{array}$}} \\
\hline & \multirow{2}{*}{4} & \multirow{2}{*}{8} & \multirow{2}{*}{12} & & & \\
\hline & & & & & fresh & dry \\
\hline 1 & 36 & 100 & 100 & 1.8 & 27 & 7 \\
\hline 2 & 27 & 80 & 100 & 2.0 & 48 & 13 \\
\hline 3 & 16 & 74 & 78 & 1.5 & 14 & 4 \\
\hline 4 & 12 & 69 & 85 & 1.5 & 24 & 7 \\
\hline 5 & 28 & 86 & 91 & 1.9 & 45 & 12 \\
\hline 6 & 8 & 61 & 71 & 1.6 & 18 & 5 \\
\hline 7 & 21 & 82 & 85 & 2.1 & 25 & 7 \\
\hline
\end{tabular}

reaction of 7 individual bulbs was compared under standard conditions as described in the methods. Table 2 clearly shows that all parameters for regeneration and growth vary considerably from bulb to bulb. Therefore, it is very dangerous to consider bulbs from the same clone, size and harvest time as reacting identical, even under perfectly controlled conditions like the test tube.

\section{Comparison of various bulb scales}

As a rule only explants from scales 7 to 18 were used, which does not necessarily imply that regeneration capacity of the various scales of different physiological age would be identical. In Table 3 the results of an experiment are shown in which three groups of bulb scales derived from 12 bulbs were compared: scales 1 to 6 , scales 7 to 12 and scales 13 to 18 . This table shows that after 4 and 8 weeks the regeneration percentage slightly increased with increasing scale numbers, but that this difference has disappeared after 12 weeks. The weight of the bulblets on the youngest scales 1 to 6 , however, is considerably lower than the bulblet weight on the older scales 7 to 12 or 13 to 18 .

Table 3. Comparison of the regeneration ability and bulb weight of various groups of bulb scales.

\begin{tabular}{|c|c|c|c|c|c|c|}
\hline \multirow[t]{3}{*}{ Scales } & \multicolumn{3}{|c|}{$\begin{array}{l}\text { Bulb regeneration } \\
\text { after } \ldots \text { weeks }(\%)\end{array}$} & \multirow{3}{*}{$\begin{array}{l}\text { Number of bulbs } \\
\text { per explant } \\
\text { after } 12 \text { weeks }\end{array}$} & \multirow{2}{*}{\multicolumn{2}{|c|}{$\begin{array}{l}\text { Total bulb weight } \\
\text { per explant (mg) } \\
\text { after } 12 \text { weeks }\end{array}$}} \\
\hline & \multirow[t]{2}{*}{4} & \multirow[t]{2}{*}{8} & \multirow[t]{2}{*}{12} & & & \\
\hline & & & & & fresh & dry \\
\hline $1-6$ & 0 & 57 & 78 & 1.8 & 11 & 3 \\
\hline $7-12$ & 3 & 67 & 88 & 1.5 & 28 & 7 \\
\hline $13-18$ & 19 & 76 & 78 & 1.6 & 25 & 6 \\
\hline
\end{tabular}

Origin of the explant in the scale

In all experiments described explants were isolated out of the basal (proximal) parts of the bulb scales. Table 4 shows the result of an experiment in which regeneration and growth of bulblets were compared in explants from the upper and from the lower parts of the scales. The data in Table 4 clearly show that the regeneration percentages,

Neth. J. agric. Sci. 21 (1973) 
Table 4. Comparison of the regeneration ability and bulb weight of explants from the upper (distal) and lower (proximal) part of bulb scales.

\begin{tabular}{|c|c|c|c|c|c|c|}
\hline \multirow[t]{3}{*}{$\begin{array}{l}\text { Origin of } \\
\text { the explant }\end{array}$} & \multicolumn{3}{|c|}{$\begin{array}{l}\text { Bulb regeneration } \\
\text { after } \ldots \text { weeks }(\%)\end{array}$} & \multirow{3}{*}{$\begin{array}{l}\text { Number of buibs } \\
\text { per explant } \\
\text { after } 12 \text { weeks }\end{array}$} & \multirow{2}{*}{\multicolumn{2}{|c|}{$\begin{array}{l}\text { Total bulb weight } \\
\text { per explant (mg) } \\
\text { after } 12 \text { weeks }\end{array}$}} \\
\hline & \multirow{2}{*}{4} & \multirow{2}{*}{8} & \multirow{2}{*}{12} & & & \\
\hline & & & & & fresh & dry \\
\hline Upper part & 0 & 20 & 30 & 0.7 & 1 & $0^{*}$ \\
\hline Lower part & 47 & 84 & 88 & 1.7 & 29 & 7 \\
\hline
\end{tabular}

* Less than $0.5 \mathrm{mg}$.

the number of bulblets per explant as well as the bulb weight per explant are drastically reduced in the upper parts as compared with the lower parts of the scales.

\section{Length of the explant}

Standard experiments were always done with explants which were $2 \mathrm{~cm}$ long and $1 \mathrm{~cm}$ wide. The influence of the length of the explants, all $1 \mathrm{~cm}$ wide, is given in Table 5 , which shows that regeneration speed, regeneration percentage after 12 weeks, number of bulblets per explant and bulb weight are proportional to the lengths of the explants. An increase in explant length from 2 to $3 \mathrm{~cm}$, which hardly results in an increase in number of bulblets per explant, strongly enhances the growth of the regenerating bulblets (see also Fig. 2).

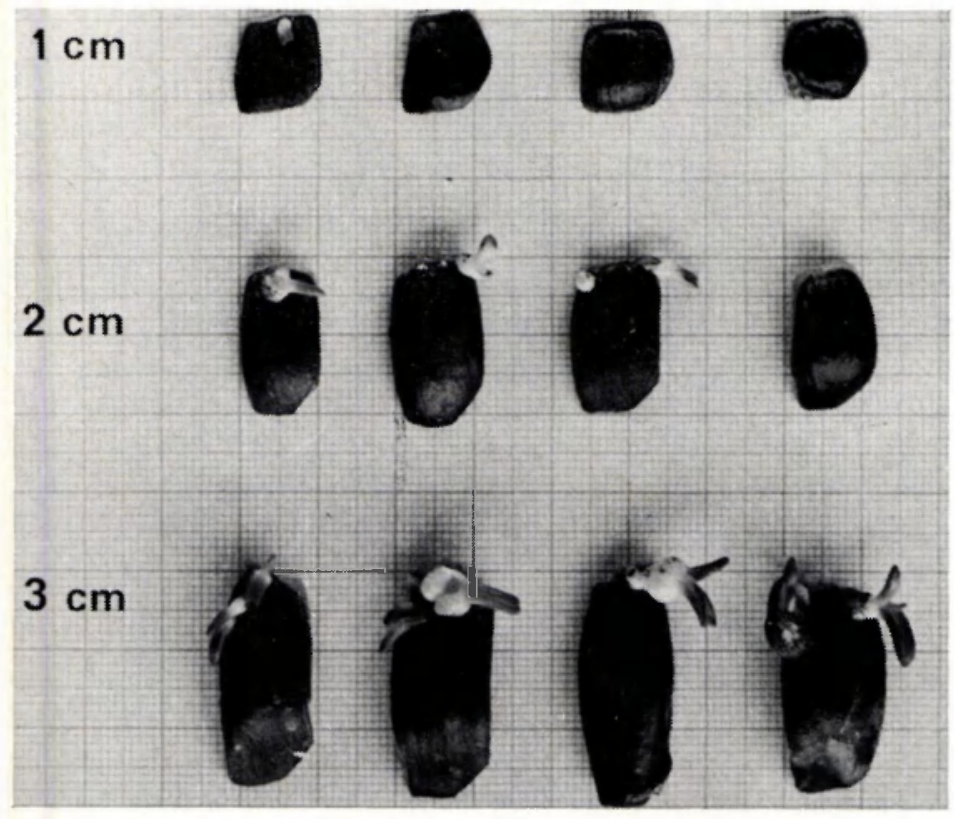

Fig. 2. The effect of the length of the explants on bulblet regeneration and bulb growth. Photograph was taken 12 weeks after isolation of the explants. See also Table 5. 
REGENERATION OF BULBLETS ON BULB SCALE SEGMENTS OF HYACINTH IN VITRO

Table 5. The effect of the length of the explants on bulb regeneration and bulb weight.

\begin{tabular}{|c|c|c|c|c|c|c|}
\hline \multirow[t]{3}{*}{$\begin{array}{l}\text { Length of the } \\
\text { explants }(\mathrm{cm})\end{array}$} & \multirow{3}{*}{$\begin{array}{l}\begin{array}{l}\text { Bulb } \\
\text { after }\end{array} \\
4\end{array}$} & \multicolumn{2}{|c|}{$\begin{array}{l}\text { regeneration } \\
\ldots \text { weeks }(\%)\end{array}$} & \multirow{3}{*}{$\begin{array}{l}\text { Number of bulbs } \\
\text { per explant } \\
\text { after } 12 \text { weeks }\end{array}$} & \multirow{2}{*}{\multicolumn{2}{|c|}{$\begin{array}{l}\text { Total bulb weight } \\
\text { per explant }(\mathrm{mg}) \\
\text { after } 12 \text { weeks }\end{array}$}} \\
\hline & & 8 & 12 & & & \\
\hline & & & & & fresh & dry \\
\hline 1 & 4 & 35 & 48 & 0.8 & 6 & 1 \\
\hline 2 & 23 & 75 & 85 & 1.7 & 37 & 9 \\
\hline 3 & 48 & 85 & 92 & 1.9 & 73 & 18 \\
\hline
\end{tabular}

\section{Orientation of the explant}

The effect of the orientation of the explant was investigated by inserting scale segments in the basic medium with their basal ends down or up. The results of this experiment are given in Table 6, which clearly shows that all regeneration and growth parameters are much higher in the inverted explants. The results of this experiment was the reason to carry out all other experiments described in this paper with inverted scale segments.

Table 6. The influence of the orientation of the explants on regeneration ability and bulb weight.

\begin{tabular}{|c|c|c|c|c|c|c|}
\hline \multirow[t]{3}{*}{$\begin{array}{l}\text { Orientation of } \\
\text { the explants }\end{array}$} & \multirow{3}{*}{$\begin{array}{l}\begin{array}{l}\text { Bulb } \\
\text { after }\end{array} \\
4\end{array}$} & \multicolumn{2}{|c|}{$\begin{array}{l}\text { regeneration } \\
\ldots \text { weeks }(\%)\end{array}$} & \multirow{3}{*}{$\begin{array}{l}\text { Number of bulbs } \\
\text { per explant } \\
\text { after } 12 \text { weeks }\end{array}$} & \multirow{2}{*}{\multicolumn{2}{|c|}{$\begin{array}{l}\text { Total bulb weight } \\
\text { per explant (mg) } \\
\text { after } 12 \text { weeks }\end{array}$}} \\
\hline & & 8 & 12 & & & \\
\hline & & & & & fresh & dry \\
\hline Basal end down & 4 & 52 & 78 & 1.2 & 18 & 4 \\
\hline Basal end up & 21 & 88 & 94 & 1.7 & 31 & 8 \\
\hline
\end{tabular}

\section{Temperature}

The effect of temperature was studied in our phytotron (Doorenbos, 1964) in continuous fluorescent light at 8.8,13.0,17.2, 21.6 and $24.8^{\circ} \mathrm{C}$. The result of this experiment is shown in Table 7 , which shows that regeneration speed increased by increasing the temperature from 8.8 to $21.6{ }^{\circ} \mathrm{C}$; at $24.8^{\circ} \mathrm{C}$ the regeneration speed is slightly lower than at $21.6^{\circ} \mathrm{C}$. The optimal temperature for the number of bulblets per explant is $13{ }^{\circ} \mathrm{C}$. The highest bulb weight per explant is reached at 21.6 or at $24.8^{\circ} \mathrm{C}$.

Table 7. Effect of temperature on bulb regeneration and bulb weight.

\begin{tabular}{|c|c|c|c|c|c|c|}
\hline \multirow[t]{3}{*}{ Temperature $\left({ }^{\circ} \mathrm{C}\right)$} & \multirow{3}{*}{$\begin{array}{l}\begin{array}{l}\text { Bulb } \\
\text { after }\end{array} \\
4\end{array}$} & \multicolumn{2}{|c|}{$\begin{array}{l}\text { regeneration } \\
\ldots \text { weeks }(\%)\end{array}$} & \multirow{3}{*}{$\begin{array}{l}\text { Number of bulbs } \\
\text { per explant } \\
\text { after } 12 \text { weeks }\end{array}$} & \multirow{2}{*}{\multicolumn{2}{|c|}{$\begin{array}{l}\text { Total bulb weight } \\
\text { per explant (mg) } \\
\text { after } 12 \text { weeks }\end{array}$}} \\
\hline & & 8 & 12 & & & \\
\hline & & & & & fresh & dry \\
\hline 8.8 & 0 & 2 & 69 & 1.9 & $0^{*}$ & $0^{*}$ \\
\hline 13.0 & 0 & 62 & 94 & 2.6 & 5 & 2 \\
\hline 17.2 & 10 & 84 & 88 & 2.1 & 37 & 11 \\
\hline 21.6 & 32 & 85 & 96 & 2.1 & 56 & 18 \\
\hline 24.8 & 25 & 70 & 86 & 1.7 & 55 & 17 \\
\hline
\end{tabular}

* Less than $0.5 \mathrm{mg}$ 
Table 8. Effect of continuous fluorescent light and darkness on regeneration ability and bulb weight.

\begin{tabular}{|c|c|c|c|c|c|c|}
\hline \multirow[t]{3}{*}{ Treatment } & \multicolumn{3}{|c|}{$\begin{array}{l}\text { Bulb regeneration } \\
\text { after } \ldots \text { weeks }(\%)\end{array}$} & \multirow[t]{3}{*}{$\begin{array}{l}\text { Number of bulbs } \\
\text { per explant } \\
\text { after } 12 \text { weeks }\end{array}$} & \multirow{2}{*}{\multicolumn{2}{|c|}{$\begin{array}{l}\text { Total bulb weigh } \\
\text { per explant (mg) } \\
\text { after } 12 \text { weeks }\end{array}$}} \\
\hline & \multirow[t]{2}{*}{4} & \multirow[t]{2}{*}{8} & \multirow[t]{2}{*}{12} & & & \\
\hline & & & & & fresh & dry \\
\hline Light & 31 & 89 & 96 & 1.6 & 51 & 13 \\
\hline Darkness & 46 & 93 & 98 & 1.6 & 57 & 13 \\
\hline
\end{tabular}

\section{Light and darkness}

In the first publication (Pierik \& Woets, 1971) on hyacinth regeneration in vitro, a remarkable difference was observed between regeneration and growth of bulblets in continuous light in comparison with darkness. An explanation could not be given. For that reason the same experiment was repeated many times. The conclusion from these experiments (see Table 8) can only be that for unknown reasons the values mentioned in our first publication are certainly wrong. Table 8 clearly shows that both regeneration and bulb weight are completely identical in continuous light in comparison with darkness.

\section{Discussion}

The number of papers concerning bulblet regeneration in vitro is very restricted. Only the regeneration of lily bulb scale segments was previously described by Robb (1957) and Hacket (1969), while Pierik \& Woets (1971) reported on bulblet regeneration in vitro of the hyacinth. Literature on hyacinth propagation in vivo by means of scooping (comparable with our vitro work) is not available, unfortunately; it seems that scooping of hyacinths is typically a practical skill of the bulb growers, which is transmitted traditionally from father to son or from horticultural school to the pupils. A practical description of scooping hyacinth can be found in a Dutch book written by Krabbendam (1962).

In the bulb industry scooping of hyacinth is done in July after harvest and drying of the bulbs, because the regenerated bulblets have to reach their maximal size before planting at the beginning of September. Krabbendam (1962) stresses that scooping of hyacinths later in the season is unfavourable. Our results in vitro, however, have shown that regeneration and growth of hyacinth bulblets certainly do not decrease when vegetative propagation takes place in October; this means for the bulb breeder that scooping can also be done much later in the season without a decrease in the multiplication rate. In contrast to our results with hyacinth, Robb (1957) showed that the regenerative capacity of isolated bulb scale segments of lily strongly depends on the season; good regeneration coincides with the periods of vegetative growth.

No indication nor explanation in literature could be found for the variability in the regeneration capacity of hyacinth bulbs of the same clone, size and harvest, as found in our study. We could not find a selection criterium for a high rate of multiplication and growth of hyacinth bulbs.

It was shown that the regenerative capacity of all hyacinth scale explants is equal, although the youngest scales ( 1 to 6 ) produce bulblets which are considerably smaller. 
Robb (1957) stated that in vitro the basal tissue of young scales of lily regenerates as early as that of mature scales. Hackett (1969), however, observed that the number and size of bulblets on lily scale segments decreased from the outer to the inner scales of the bulb. Our conclusion for hyacinth is intermediate between the above cited conclusions for lily, but is completely in accordance with Rees (1972), who stated for two lily species that rapid and good bulblet production was obtained only from the outer and middle scales of parent bulbs.

That proximal explants of hyacinth form more and larger bulblets than the distal sections is in agreement with the in vitro work on lily scale explants by Robb (1957) and Hackett (1969). Robb (1957) even stated that distal explants of lily scales never regenerated bulblets. Krabbendam's (1962) remark that hyacinth bulbs must not be scooped too deeply agrees with the conclusions for lily and hyacinth mentioned above. The length of the explant (mass of scale tissue isolated) was shown to be a master factor, both in the regeneration process and in the growth of the bulblets. Therefore, it can be concluded that the distal parts also play an important role, possibly as a source of carbohydrates and other substances.

A clear positive effect was found when hyacinth explants were placed inverted on the media. A similar 'orientation effect' was also described by Hackett (1969) for lily explants. The first explanation for this positive effect can be a bad oxygen supply at the basal ends in the medium and a good oxygen supply at the basal ends of the inverted explants. A second explanation can be that accumulation of substances (hormonal and nutritional) at the basal parts is much better in inverted explants in contrast to explants with their basal ends in the agar; in the latter case depletion of essential substances can occur when they diffuse from the basal ends into the agar.

Low temperature $\left(13^{\circ} \mathrm{C}\right)$ was shown to be optimal for the number of regenerating bulblets, although their growth at that temperature is poor. In bulb growing practice scooped hyacinth bulbs are first placed at $20^{\circ} \mathrm{C}$ and later the temperature is gradually increased to $25-26^{\circ} \mathrm{C}$ (Krabbendam, 1962). Our in vitro experiments showed that a high temperature is optimal for growth. The promoting effect of low temperature on bulblet regeneration in hyacinth can possibly be explained in terms of hormonal levels, which are sometimes clearly affected by temperature: both Heide (1964) for Begonia and Appelgren \& Heide (1972) for Streptocarpus showed that low temperatures promoted adventitious bud formation.

In bulb growing practice hardly anything is known about the effect of light or darkness on regeneration and growth of bulblets. The fact that bulb growers prefer to place their scooped hyacinth bulbs immediately in darkness only indicates that darkness seems to be more favourable than light (Krabbendam, 1962). Our in vitro experiments with hyacinth do not support this view; Hacket (1969) also demonstrated that bulblet formation from lily scale explants occurs just as well in light as in the dark. It seems worth while to study the effect of light in comparison to darkness on scooped hyacinths.

\section{Acknowledgments}

We are greatly indepted to Miss Tiny Steegmans for her valuable technical assistance, and to the Royal Netherlands Bulb Nurseries, Van Zanten Brothers, Hillegom, for the supply of the hyacinth bulbs. 


\section{References}

Appelgren, M. \& O. M. Heide, 1972. Regeneration in Streptocarpus leaf discs and its regulation by temperature and growth substances. Physiologia Pl. 27: 417-423.

Doorenbos, J., 1964. Het fytotron van het Laboratorium voor Tuinbouwplantenteelt. Meded. Dir. Tuinb. 27: 432-437 (Dutch).

Forsberg, J. L., 1969. An unexpected effect of Benomyl on two gladiolus varieties. Pl. Dis. Reptr 53: 318-319.

Hackett, W. P., 1969. Aseptic multiplication of lily bulblets from bulb scales. Proc. Meet. Int. Pl.. Prop. Soc.: 105-108.

Heide, O. M., 1964. Effect of light and temperature on the regeneration ability of Begonia leaf cuttings. Physiologia Pl. 17: 789-804.

Krabbendam, P., 1962. Bloembollenteelt, III. De hyacint. Tjeenk Willink, Zwolle, pp. 142 (Dutch).

Pierik, R. L. M. \& J. Woets, 1971. Regeneration of isolated bulb scale segments of hyacinth. Acta Hort. 23 (2): $423-428$.

Rees, A. R., 1972. The growth of bulbs, Applied aspects of the physiology of ornamental bulbous crop plants. Academic Press, London/New York, pp. 311.

Robb, S. M., 1957. The culture of excised tissue from bulb scales of Lilium speciosum Thun. J. exp. Bot., 8: 348-352. 